\title{
Thermal power plant cooperation with wind turbines
}

\author{
Ivo Palu, Heiki Tammoja and Rein Oidram \\ Department of Electrical Power Engineering, Tallinn University of Technology, Ehitajate tee 5, \\ 19086 Tallinn, Estonia; ivo.palu@ttu.ee \\ Received 13 March 2008, in revised form 26 September 2008
}

\begin{abstract}
The popularity of wind energy is increasing and that arises several technical problems like system stability and wind power reliability. Power companies have learned how to predict power consumption and therefore know how to plan power generation. Adding notable amount of wind power into the system requires a new approach to system stability. The idea of wind power is to reduce the domination of fossil fuel and to decrease emissions. This issue is very important in Estonia, where mainly thermal power plants are used for power production. In this paper cooperation between wind turbines and a conventional power plant is analysed. As the result of this analysis, the supplementary emission caused by using conventional power plants for balancing wind turbines is calculated.
\end{abstract}

Key words: wind turbines, partial load, emission reduction, gas engine power plant.

\section{INTRODUCTION}

The usage of renewable energy sources, especially of wind energy, is increasing rapidly. During last decades, Europe has taken a giant step in the field of wind energy, starting from Denmark and with new wind energy peaks in Germany and Spain. Denmark, as the country with the longest history of modern wind energy, is planning to have $50 \%$ of its electricity in 2050 from wind energy $\left[{ }^{1,2}\right]$. At the end of 2006 the EU set its renewable energy target on $20 \%$ from overall energy consumption by the year $2020\left[^{3}\right]$. The proportion of wind energy could be by the year 2020 as high as $13 \%$ of the EU electricity demand according to EWEA $\left[{ }^{4}\right]$. This means $180 \mathrm{GW}$ of installed capacity of wind turbines, while in the year 2006 the total capacity in EU was $48 \mathrm{GW}$. The quadruple increase should take place within the next 12 years. This all will be integrated into a grid, already containing conventional power plants (coal, oilshale or gas fired) and nuclear power plants. If the balancing has to be made with gas turbines, the large numbers of engine starts and stops has a significant 
negative effect on the performance and lifetime of the turbines $\left[{ }^{5,6}\right]$. Systems, based on hydropower, are in privileged situation since they already have fossilfree energy generation together with fast regulating power source. It is stated in $\left[{ }^{7}\right]$ that for a hydro-dominated system wind power regulation is not a problem, but other issues are likely to arise before the regulation.

\section{UNCERTAINTY OF THE WIND POWER}

The main problem in the use of wind turbines is the high power fluctuation. Figure 1 shows the electricity generation at Pakri wind park in December 2006, where 8 turbines with total installed capacity of $18.4 \mathrm{MW}$ were erected in 2005.

If we take the annual power generation of the wind park and transform it into a histogram, we get the picture shown in Fig. 2. Most of the working hours through the year are in the low generation part and the average wind park power output is $4.88 \mathrm{MW}$, which is $27 \%$ of the installed capacity.

It is very complicated to use this type of power in power systems consisting mainly of base load power plants like in Estonia. The total installed capacity of wind turbines in Estonia is 56 MW (October 2007). Estonian Grid Company has stated that maximum amount of wind power that could be integrated into the power system, is $720 \mathrm{MW}$ because of our weak interconnections to other EU countries. We have one $350 \mathrm{MW}$ connection to Nordic countries through Estlink submarine cable. Wind power development plans in Estonia are ambitious, as there are more than $2500 \mathrm{MW}$ installations in the pipeline. It is needless to say that this amount of installed power can not be integrated without new connections to neighbouring countries. We must consider that Estonian minimum power consumption is around $500 \mathrm{MW}$ during mid summer and maximum $1700 \mathrm{MW}$ in winter.

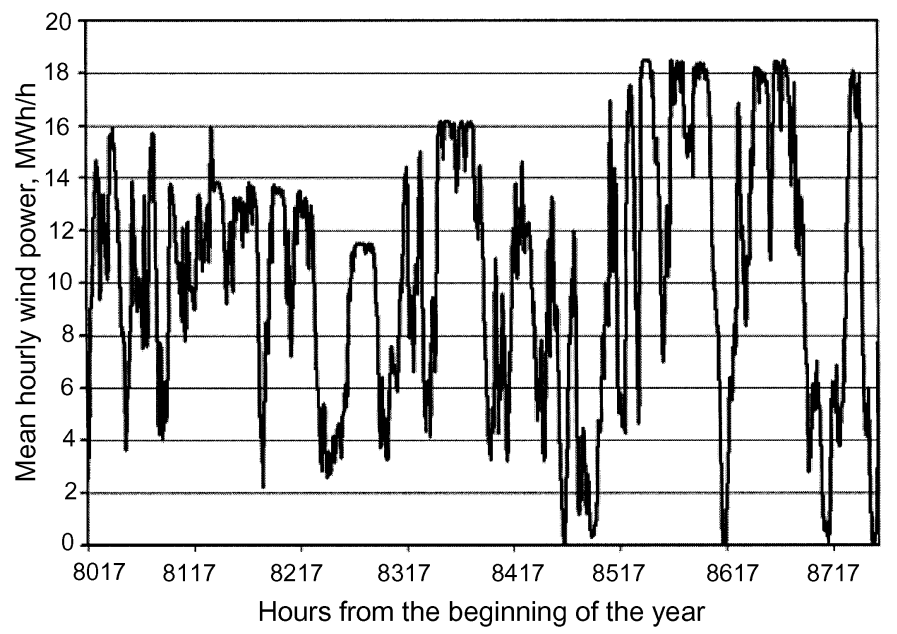

Fig. 1. Electricity generation per hour by the Pakri Wind Park in December 2006. 


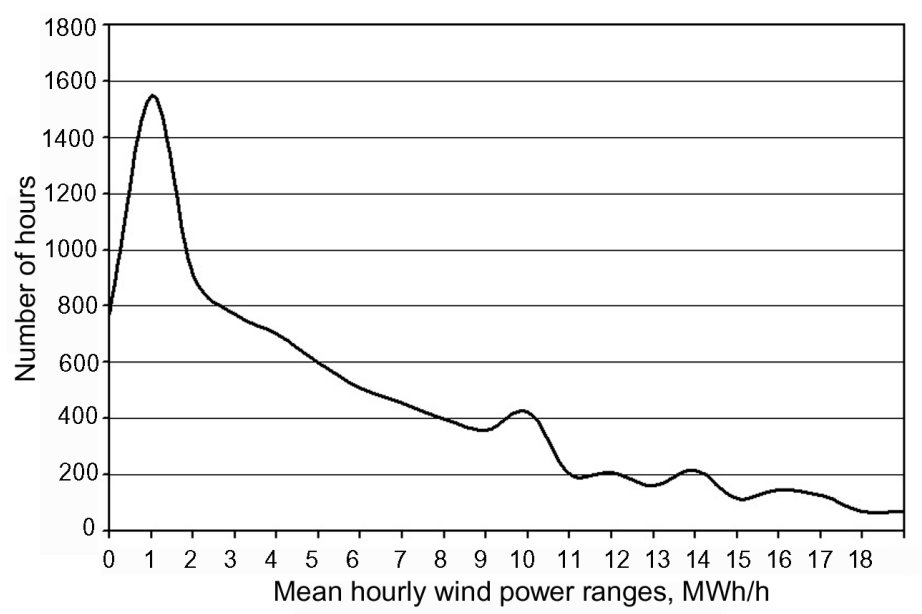

Fig. 2. Electricity generation histogram in 2006 at the Pakri Wind Park.

\section{BALANCING WIND POWER WITH CONVENTIONAL POWER PLANTS}

All the time there has to be a balance between electricity consumption and generation. Electricity unbalance causes several problems for system stability and therefore it must be avoided. Base load in power systems are covered with big thermal power plants. Gas turbines and gas engines are only used occasionally to cover peak loads. Due to relatively high operational cost, the working hours of gas turbines is kept as low as possible. According to $\left.{ }^{8}\right]$, in Denmark in 2007 the installed $741 \mathrm{MW}$ of gas turbines generated $60 \mathrm{GWh}$ of electricity, which gives the utilization period at maximum capacity equal to $80 \mathrm{~h}$.

The balancing in power systems is preferably made with hydropower plants. If there are no hydropower plants in the system or there is no water for regulation, the gas turbines or gas engines are to be used. When we start to use power generation based on gas for balancing the wind power, the working hours of gas turbines or engines are increasing together with emissions. Today the balance in Estonia is currently regulated by oil-shale power plants, which are not designed for that purpose. These plants are base load power plants and $93 \%$ of the electricity, consumed in Estonia, is generated by them. The regulating capacity for a steam turbine is $5 \mathrm{MW}$ per minute. If we erect more wind turbines, we have to use the regulating capability of Estonian oil-shale fired power plants. Besides thermal power plants, there are only some small combined heat and power (CHP) plants, but they are following the heat load. Therefore new fast regulating units have to be installed.

Let us examine the conditions for balancing the power, produced by wind turbines. Exact calculations require large quantities of data, which are complicated to obtain. To estimate fuel consumption in oil-shale based thermal power plants is complicated. The main option is to measure it from load characteristics. If we need to balance wind power fluctuations with these thermal plants, the precise measur- 
ing of fuel consumption is even more complicated. That is why this problem is not investigated and only slightly mentioned in $\left[{ }^{9-11}\right]$.

Not knowing the precise load-dependent fuel consumption of oil-shale power plants we have used the gas engine power plant in our calculations. This reflects the future situation, when wind park owners must predict their wind generation and if needed, have to use other energy sources besides wind energy.

The power station efficiency depends on the load $\left[{ }^{12}\right]$. Partial load of the engine is undesirable because it reduces the engine efficiency $\left[{ }^{5}\right]$. As shown in Fig. 3, the most effective electricity generation takes place, when the unit is fully loaded. If we have to balance wind fluctuations, we will have to operate at times at partial load with higher specific fuel consumption.

If the power plant is operating at partial load, when the efficiency is lower, the emission of hazardous gases remains the same or even increases (Fig. 4) $\left[{ }^{12,13}\right]$.

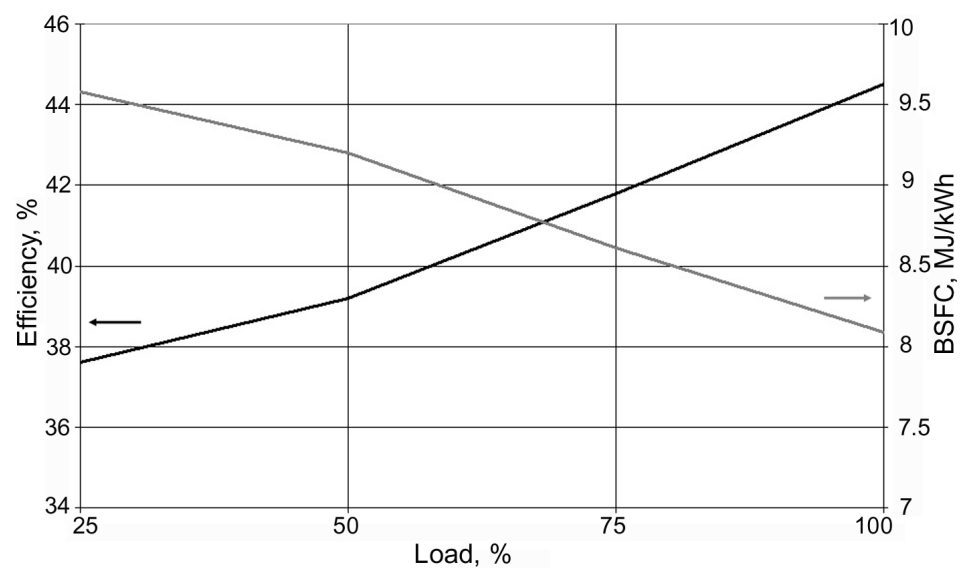

Fig. 3. Gas engine power plant efficiency and brake specific fuel consumption (BSFC) dependence on the load $\left[{ }^{13}\right]$.

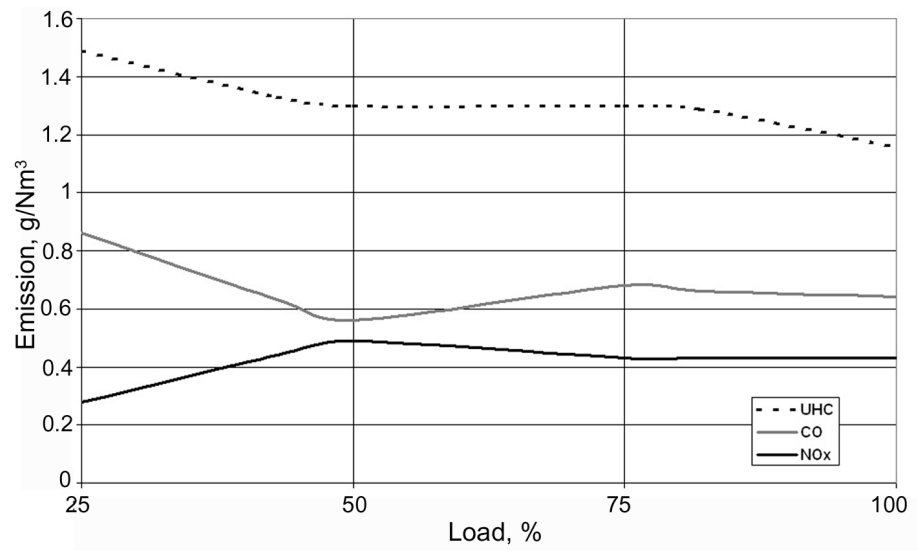

Fig. 4. Gas engine power plant emission dependence on the load $\left[{ }^{13}\right]$ : UHC - unburned hydrocarbon; $\mathrm{CO}$ - carbon monoxide; $\mathrm{NO}_{\mathrm{x}}-$ nitrogen oxides. 
By balancing the wind power, the unit is used ineffectively, resulting in notably lower emission reduction as expected. The engine is designed to work most efficiently at full power. When we start to manoeuvre with the load, we are moving along the efficiency curve.

\section{EMISSION CALCULATIONS DUE TO BALANCING}

Load forecast in the power system is made from several years and months up to hours ahead. If the wind power plant is considered as a conventional power plant, it must have its power generation forecast. The accuracy of a wind power generation forecast is generally between $10 \%$ and $20 \%$, while some errors in high wind might be as large as $35 \%$ or more $\left[{ }^{14,15}\right]$. High quality forecasting of the power output of wind turbines is required for improving the management of the balancing power from traditional power plants. The forecasting periods (days) are managed using meteorological forecast data. The quality of meteorological forecast is not yet sufficient to allow accurate prediction at individual sites.

In the following example we have used one-hour average prediction with maximum error of 15\%. Wind statistics from the Pakri Wind Park represent local wind conditions and, as it can be seen from Fig. 1, there are almost $800 \mathrm{~h}$ per year without electricity production (range from 0 to $1 \mathrm{MW}$ ). Therefore, we have used wind distribution in Denmark, as it describes wind distribution over a larger area instead of one wind park. This also eliminates maintenance errors, which might occur when analysing a single wind park.

The emission calculations are based on the Caterpillar GCM 34 gas engine with rated power $6.1 \mathrm{MW}$ working on natural gas $\left[{ }^{13}\right]$. Engine efficiency, emission and rated fuel consumption graphs are shown in Figs. 3 and 4.

To have a case study about balancing wind turbines with conventional power plants, several simplifications have been made in the calculations. We have created a situation where wind park owners must predict the next day hourly wind generation. If the generation is less than predicted, the underprovided electricity must be covered by the gas engine. The situation, when the power output is more than predicted, has not been analysed here as there are several options to solve it, like limiting power output of wind turbines or transferring the balancing problem to others by giving electricity away for free.

So we have a closed system, which contains $30 \mathrm{MW}$ of wind turbines and a 6.1 MW gas engine to assure the predicted power output. During the time when the wind power forecast is more than $8 \mathrm{MW}$, the power output from the gas engine is $1.525 \mathrm{MW}$, which is $25 \%$ of its rated power. The engine can balance wind energy error on maximum output, when forecast error is not larger than $20 \%$. If error is larger than $20 \%$, other sources have to be used. If predicted wind power generation is less than $20 \%$ of the installed capacity, the gas engine power station is stopped.

Results shown in Fig. 5 are similar to the current situation in power systems containing only thermal power plants. Figure 5 shows the electricity, generated 


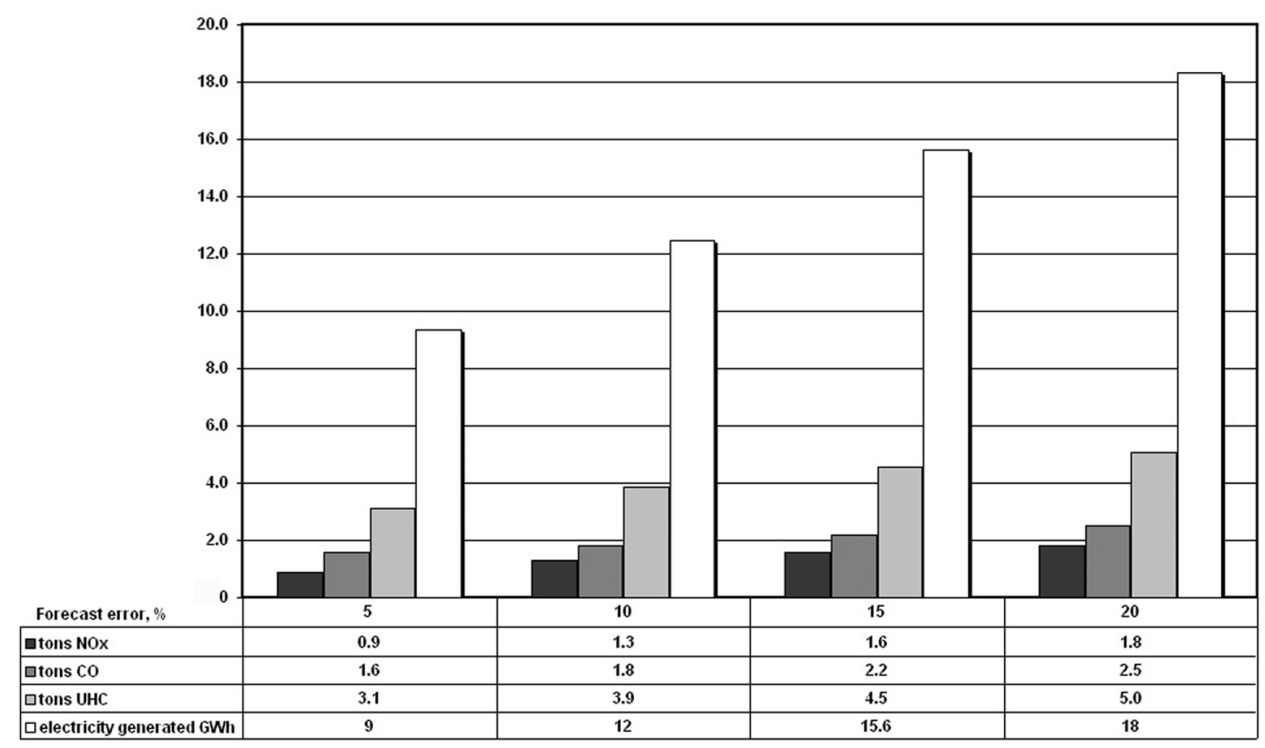

Fig. 5. Annual electricity generation and emission of the gas engine power plant depending on the forecast error.

by gas turbines when used to balance the wind turbines forecast error. In the case of $15 \%$ forecast error, during one year the $30 \mathrm{MW}$ of wind power would have generated $53.4 \mathrm{GWh}$ and the gas engine $15.6 \mathrm{GWh}$ by burning 3.5 million $\mathrm{m}^{3}$ of natural gas. Due to the balancing wind energy shortages during this year, the gas engines power plant has emitted $2.2 \mathrm{t}$ of $\mathrm{CO}, 1.6 \mathrm{t}$ of $\mathrm{NO}_{\mathrm{x}}$ and $4.5 \mathrm{t}$ of $\mathrm{UHC}$. The power plant has operated on partial load with average efficiency $40.6 \%$, compared to the efficiency at full load $44.5 \%$.

\section{CONCLUSIONS}

The amount of the emitted hazardous gases and reduced efficiency of working units show that it is not an emission-free way to balance wind fluctuations with conventional power plants. The supplementary generation can not be avoided, because electricity balance in the system must be guaranteed. Emission can be further reduced if we can raise the wind speed forecasting quality, but the need for keeping the balancing reserves still remains. One possibility to avoid these emissions is to start using intermediate energy accumulation. For example, we could store energy, generated by wind turbines, in heat accumulators or pump water in pumped hydropower plants and use it when wind energy is not available. The surplus wind energy could also be used to produce secondary fuels like hydrogen.

In systems containing mainly fossil fuel power plants, the positive effect of wind turbines is notably smaller than expected. The example showed that already 
$30 \mathrm{MW}$ of wind power needs balancing reserves, where hazardous gases are emitted. If we plan to erect more than $700 \mathrm{MW}$ of wind power, the positive effect of wind turbines is notably lower than assumed. The balancing problem of the wind power requires new fast regulating units or accumulators to be installed. This makes the integration of wind turbines more expensive and extends the payback time of total investments. Today we are balancing our $56 \mathrm{MW}$ wind power with oil-shale based thermal power plants, from where more gases and ash compared to the above example are emitted. As long as we do not have any hydropower or accumulators to avoid this, we cannot talk about wind energy as purely emission-free power generation. Also the emission reduction caused by wind turbines in this case should be reconsidered.

\section{ACKNOWLEDGEMENT}

Authors thank the Estonian Science Foundation (grant No. 5885) for financial support of this study.

\section{REFERENCES}

1. Lund, H. Large-scale integration of wind power into different energy systems. Energy, 2005, 30, 2402-2412.

2. Eriksen, P. B. and Orths, A. The challenges and solutions of going from 20 to 50 percent of wind energy coverage in the Danish power system until 2025. In Proc. 7th International Workshop on Large-Scale Integration of Wind Power into Power Systems as well as on Transmission Networks for Offshore Wind Farms. Madrid, 2008.

3. A Renewable Energy Roadmap: Paving the Way Towards a 20\% Share of Renewables in the EU's Energy Mix by 2020. European Union press release, 10 January 2007, MEMO/07/13. $\mathrm{http} / / /$ europa.eu/rapid/pressReleasesAction.do?reference=MEMO/07/13 (25.08.08).

4. Making $180 \mathrm{GW}$ a Reality by 2020. EWEA's Position on the Future EU Legislation for Renewable Energy and Its Impact on the Wind Industry. Executive summary. http://www.ewea.org/fileadmin/ewea_documents/documents/news_releases/EXECUTIVE_ SUMMARY_rev.pdf (16.09.08).

5. Fragaki, A., Andersen, A. N. and Toke, D. Exploration of economical sizing of gas engine and thermal store for combined heat and power plants in the UK. Energy, 2008, 33; doi:10.1016/j.energy.2008.05.011.

6. Haeseldonckx, D., Peeters, L., Helsen, L. and D'haeseleer, W. The impact of thermal storage on the operational behaviour of residential CHP facilities and the overall $\mathrm{CO}_{2}$ emissions. Renewable and Sustainable Energy Rev., 2007, 11, 1227-1243.

7. Kiviluoma, J. and Holttinen, H. Impacts of wind power on energy balance of hydro dominated power system. In Proc. European Wind Power Conference. Athens, 2006.

8. Nordel Annual statistics 2007. Nordel Secretariat, Norway.

9. Liik, O., Oidram, R., Keel, M., Ojangu, J., Landsberg, M. and Dorovatovski, N. Co-operation of Estonia's oil shale-based power system with wind turbines. Oil Shale, 2005, 22, $127-$ 142.

10. Leonhard, W. and Müller, K. Balancing fluctuating wind energy with fossil power stations. Where are the limits? Electra, 2002, 204, 12-17.

11. Liik, O., Oidram, R., Keel, M. and Landsberg, M. A new method for estimation of fuel savings by wind energy and its impact on power systems planning. In Proc. Power-Gen Europe. Barcelona, 2004, paper 357, 1-18. 
12. Kaewboonsong, W., Kuprianov, V. I. and Chovichien, N. Minimizing fuel and environmental costs for a variable-load power plant (co-)firing fuel oil and natural gas: Part 1. Modeling of gaseous emissions from boiler units. Fuel Process. Technol., 2006, 87, 1085-1094.

13. Power Plant Project Guide for CM Engines. Caterpillar INC. 2002.

14. Ahlstrom, M. L. and Zavadil, R. M. The role of wind forecasting in grid operations. In Proc. Reliability, Transmission and Distribution Conference and Exhibition: Asia and Pacific. Dalian, China, 2005. IEEE/PES, 2005.

15. Giebel, G. The State-Of-The-Art in Short-Term Prediction of Wind Power. A Literature Overview. Ris $\varnothing$ National Laboratory, Ris $\varnothing, 2003$.

\section{Soojuselektrijaamade koostöö elektrituulikutega}

\section{Ivo Palu, Heiki Tammoja ja Rein Oidram}

Tuuleenergia kasutamine kasvab, mis tõstatab mitmeid tehnilisi probleeme, nagu süsteemi stabiilsus ja tuuleenergia usaldatavus. Energiaettevõtted oskavad suhteliselt täpselt prognoosida elektrienergia tarbimist ja seeläbi ka tootmist. Lisades olemasolevasse süsteemi märgatavas koguses tuuleenergiat, vajavad seni kehtivad põhitõed ümbervaatamist. Elektrituulikute püstitamise peamine ja algne idee oli vähendada elektrienergia tootmisel fossiilkütuste osakaalu ning sellest tulenevat keskkonnasaastet. Just viimane asjaolu on Eestis väga tähtis, sest seni on elektrienergiat toodetud ja süsteemi võimsusbilanssi hoitud suurte põlevkivi põletavate soojuselektrijaamadega. Käesolevas artiklis on analüüsitud elektrituulikute ja kiirelt reguleeritavate gaasil põhinevate soojuselektrijaamade koostööd. On näidatud, et kütust põletavates elektrijaamades, kui neid kasutada tuuleenergia tasakaalustamiseks, tekib täiendav emissioon. Seda saaks vähendada, parandades tuule kiiruse prognoosi või kasutades vaheetapina tuuleelektri akumuleerimist. Süsteemis, mis koosneb peamiselt fossiilkütuseid põletavatest soojuselektrijaamadest, on tuulikute positiivne efekt märkimisväärselt väiksem kui näiteks hüdroenergiat tasakaalustamiseks kasutavas elektrivõrgus. Niikaua kui meil ei ole tuuleenergia akumuleerimise võimalusi, ei saa tuuleenergiast rääkida kui heitmevabast elektritootmisviisist. 